\title{
Implementasi Metode Fuzzy Sugeno Pada Penentuan Harga Emas 24 Karat pada Kota Medan
}

\author{
Fildzah Nadya Arieni ${ }^{1}$, Dhea Halimah ${ }^{2}$, Ira Audita ${ }^{3}$ \\ ${ }^{1,2,3}$ Mahasiswa STIKOM Tunas Bangsa, Pematangsiantar - Indonesia \\ Jln. Sudirman Blok A No. 1-3 Pematangsiantar, Sumatera Utara \\ Ifildzahna@gmail.com, ${ }^{2}$ dheahalimah@gmail.com, ${ }^{3}$ iraaudita@gmail.com
}

\begin{abstract}
Gold is one of the most precious precious metals by the public because gold prices tend to be stable and increase every month, gold investment has also developed quite rapidly. Gold can be invested in various forms such as gold bars and gold in the form of jewelry that has value to add to the wearer's appearance besides that there is also gold in the form of ancient currency coins that have historical value and are usually kept by collectors, gold is one form of investment that is not influenced by trends in society because gold is bought by everyone at any time. The purpose of this study was to determine the determination of the price of 24 carat gold in medan city. In this study, the authors used 3 criteria including demand, quality and price.
\end{abstract}

Keywords: Fuzzy, Sugeno, Emas, Medan, Application

\begin{abstract}
Abstrak
Emas merupakan salah satu logam mulia yang paling banyak diminati oleh masyarakat dikarenakan harga emas yang cenderung stabil dan mengalami kenaikan setiap bulannya, investasi emas juga sudah berkembang cukup pesat. Emas dapat diinvestasikan dalam berbagai bentuk seperti emas batangan dan emas dalam bentuk perhiasan yang memiliki nilai untuk menambah penampilan pemakainya selain itu juga ada emas dalam bentuk koin mata uang kuno yang memiliki nilai historis dan biasanya disimpan oleh kolektor, emas merupakan salah satu bentuk investasi yang tidak dipengaruhi oleh tren di masyarakat karena emas banyak dibeli oleh setiap orang di waktu kapanpun. Tujuan dari penelitian ini adalah untuk mengetahui penentuan harga emas 24 karat di kota medan. Pada penelitian ini, penulis menggunakan 3 kriteria antara lain permintaan, kualitas dan harga.
\end{abstract}

Kata Kunci: Fuzzy, Sugeno, Emas, Medan, Penerapan

\section{Pendahuluan}

Peran emas dalam perekonomian Indonesia semakin tinggi. Emas semakin dicari oleh semua orang karena emas adalah investasi yang sangat menjanjikan. Faktorfaktor rasional dan berbagai faktor tidak rasional menjadi faktor penentu dalam pembelian emas. Faktor rasional umumnya berkaitan dengan analisis fundamental. Analisis ini difokuskan dan dilakukan terhadap aspek fundamental seperti laba per gram emas, deviden per gram emas, struktur permodalan, dan potensi pertumbuhan. Pada dasarnya, pendekatan ini menekankan nilai atau harga emas berdasarkan laba yang akan diperoleh dari emas tersebut. Analisis fundamental tidak memperhatikan pada pola pergerakan emas di masa silam tetapi berusaha menentukan nilai yang tepat untuk sebuah emas. Karenanya emas adalah investasi jangka panjang yang sangat menjanjikan [1]. Menurut Andini dan Rahardjo (2012) [2], harga merupakan faktor yang berpengaruh secara signifikan terhadap keputusan pembelian oleh konsumen dalam transaksi jual beli. Dengan demikian, penentuan harga jual emas Emas menjadi suatu pertimbangan oleh pemilik Toko.

Tinggi rendahnya harga emas dipengaruhi oleh banyak faktor seperti kondisi dan kinerja perusahaan, resiko, deviden, tingkat suku bunga, kondisi perekonomian, 
kebijaksanaan pemerintah, laju inflasi, penawaran dan permintaan serta masih banyak lagi. Karena dimungkinkan adanya perubahan faktor-faktor di atas, harga emas dapat naik atau turun tanpa dapat diduga. Oleh karena itu dalam penelitian ini dibahas penerapan metode fuzzy Sugeno untuk menentukan harga emas. Penelitian ini dilakukan untuk mengetahui bagaimana menentukan harga jual emas dengan menggunakan metode fuzzy Sugeno.

\section{Metodologi Penelitian}

\subsection{Metode Sugeno}

Model Fuzzy Sugeno (model fuzzy TSK) diajukan oleh Takagi, Sugeno, dan Kang ( Takagi dan Sugeno, 1985) dalam upaya untuk membangun pendekatan sistematis untuk membangkitkan aturan - aturan fuzzy dari himpunan data Input - Output yang diberikan. Suatu aturan fuzzy khas dalam model fuzzy Sugeno dibentuk:

if $\mathrm{x}$ is $\mathrm{A}$ and $\mathrm{y}$ is $\mathrm{B}$ then $\mathrm{z}=\mathrm{f}(\mathrm{x}, \mathrm{y})$, dimana $\mathrm{A}$ dan $\mathrm{B}$ himpunan fuzzy dalam anteseden dan $z=f(x, y)$ fungsi tegas dalam konsekuen. Jika $f(x, y)$ polimonial orde satu, FIS yang dihasilkan disebut model fuzzy Sugeno orde satu. Jika f konstan, dihasilkan model fuzzy Sugeno orde nol. Sistem inferensi fuzzy menggunakan metode Sugeno memiliki karakteristik, yaitu konsekuen tidak merupakan himpunan fuzzy, namun merupakan suatu persamaan linear dengan variabel - variabel sesuai dengan variabel - variabel Inputnya [3].

\subsection{Penalaran Fuzzy Metode Sugeno}

Penalaran dengan metode Sugeno hampir sama dengan penalaran Mamdani, hanya saja Output (konsekuen) sistem tidak berupa himpunan Fuzzy, melainkan berupa konstanta atau persamaan linear. Michio Sugeno mengusulkan penggunaan singleton sebagai fungsi keanggotaan dari konsekuen. Singleton adalah sebuah himpunan Fuzzy dengan fungsi keanggotaan yang pada titik tertentu mempunyai sebuah nilai dan 0 di luar titik tersebut [4].

\subsection{Penalaran Fuzzy Metode Sugeno}

Penalaran dengan metode Sugeno hampir sama dengan penalaran Mamdani, hanya saja Output (konsekuen) sistem tidak berupa himpunan Fuzzy, melainkan berupa konstanta atau persamaan linear. Michio Sugeno mengusulkan penggunaan singleton sebagai fungsi keanggotaan dari konsekuen. Singleton adalah sebuah himpunan Fuzzy dengan fungsi keanggotaan yang pada titik tertentu mempunyai sebuah nilai dan 0 di luar titik tersebut [5].

\section{Hasil dan Pembahasan}

\subsection{Data}

Pada penelitian ini, sumber data penelitian diperoleh dari Badan Pusat Statistik Sumatera Utara (BPS Sumut) dimana data tersebut adalah data Harga Emas 24 Karat di Kota Medan melalui situs https://www.sumut.bps.go.id. Bahan penelitian yang dipakai berupa data sekunder yang terdiri dari data Permintaan, data Kualitas, dan data Harga Emas Disesuaikan pada tahun 2017. Data tersebut dapat dilihat dalam tabel berikut:

Tabel 1. Data Permintaan, Kualitas, dan Harga Emas tahun 2017

\begin{tabular}{|l|l|l|l|}
\hline Bulan & Permintaan & Kualitas & Harga Emas Tahun 2017 \\
\hline Januari & 10 & 2 & 503486 \\
\hline Februari & 9 & 8 & 508679 \\
\hline Maret & 20 & 6 & 518750 \\
\hline April & 5 & 4 & 520750 \\
\hline Mei & 22 & 5 & 520600 \\
\hline
\end{tabular}




\begin{tabular}{|l|l|l|l|}
\hline Bulan & Permintaan & Kualitas & Harga Emas Tahun 2017 \\
\hline Juni & 15 & 7 & 521543 \\
\hline
\end{tabular}

Pada penelitian ini, penulis mengambil contoh permasalahan yakni berapakah harga emas per gram jika permintaan $=20$, dan kualitas $=8$ ?. Proses perhitungan logika fuzzy sugeno dilakukan dengan melalui tahapan-tahapan sebagai berikut:

\subsection{Proses Perhitungan Logika Fuzzy Metode Sugeno}

a. Pembentukan Himpunan Fuzzy (fuzzifikasi)

Pada metode Fuzzy sugeno, baik variabel Input maupun Output dibagi menjadi satu atau lebih himpunan Fuzzy. Variabel Input dibagi menjadi dua yaitu variabel permintaan dan kualitas, sedangkan yang menjadi variabel Output adalah harga. Penentuan variabel yang digunakan dalam penelitian ini, terlihat pada Tabel 2 :

Tabel 2. Penentuan Variabel dan Semesta Pembicaraan

\begin{tabular}{|l|l|l|}
\hline Fungsi & Nama Variabel & Semesta Pembicaraan \\
\hline Input & Permintaan $(\mathrm{X})$ & {$[1-40]$} \\
\cline { 2 - 3 } & Kualitas $(\mathrm{Y})$ & {$[1-10]$} \\
\hline Output & Harga Emas $(\mathrm{Z})$ & {$[500000-530000]$} \\
\hline
\end{tabular}

Tabel 3. Himpunan Fuzzy

\begin{tabular}{|l|l|l|}
\hline Fungsi & Nama Variabel & Domain \\
\hline Input & Permintaan $(\mathrm{X})$ & {$[5-30]$} \\
\cline { 2 - 3 } & Kualitas $(\mathrm{Y})$ & {$[2-9]$} \\
\hline Output & Harga Emas (Z) & {$[500000-525000]$} \\
\hline
\end{tabular}

b. Pembentukan Fuzzy Rule

Pada tahap ini, nilai keanggotaan himpunan harga dan kualitas saat ini dicari menggunakan fungsi keanggotaan himpunan Fuzzy berdasarkan data. Pembentukan Aturan Fuzzy, Dari dua variabel Input dan sebuah variabel Output yang telah didefinisikan, dengan melakukan analisa data terhadap batas tiap-tiap himpunan Fuzzy pada tiap-tiap variabelnya maka terdapat 6 aturan Fuzzy yang akan dipakai dalam sistem ini, dengan susunan aturan IF permintaan IS ... AND kualitas IS ... THEN harga IS.

[R1] IF Permintaan SEDIKIT AND Kualitas KURANG BAIK THEN Harga MURAH

[R2] IF Permintaan SEDIKIT AND Kualitas BAIK THEN Harga MURAH

[R3] IF Permintaan BANYAK AND Kualitas BAIK THEN Harga MAHAL

[R4] IF Permintaan SEDIKIT AND Kualitas KURANG BAIK THEN Harga MAHAL

[R5] IF Permintaan BANYAK AND Kualitas KURANG BAIK THEN Harga MAHAL

[R6] IF Permintaan SEDIKIT AND Kualitas BAIK THEN Harga MAHAL

Berikut adalah cara untuk mendapatkan nilai keanggotan berdasarkan variabel linguistik dan variabel numerik yang digunakan:

1) Fungsi keanggotaan himpunan Fuzzy SEDIKIT, dan BANYAK dari variabel Permintaan

$$
\begin{aligned}
& \mu X[\text { SEDIKIT }]=\left\{\begin{aligned}
1, & x \leq 5 ; \\
\frac{30-x}{30-5}, & 5 \leq x \leq 30 ; \\
0, & x \geq 30 ;
\end{aligned}\right. \\
& \mu X[\text { BANYAK }]=\left\{\begin{aligned}
0, & x \geq 30 ; \\
\frac{x-5}{30-5}, & 5 \leq x \leq 30 ; \\
1, & x \leq 5 ;
\end{aligned}\right.
\end{aligned}
$$


Mencari nilai keanggotaan untuk Variabel Permintaan:

$\mu$ Sedikit $[20]=(30-20) / 25=0,4$

$\mu$ Banyak $[20]=(20-5) / 25=0,6$

2) Fungsi keanggotaan himpunan Fuzzy KURANG BAIK, dan BAIK dari variabel Kualitas

$$
\begin{gathered}
\mu Y\left[\text { KURANG BAIK] }=\left\{\begin{array}{cc}
1, & y \leq 2 ; \\
\frac{9-y}{9-2}, & 2 \leq y \leq 9 ; \\
0, & x \geq 9 ;
\end{array}\right.\right. \\
\mu Y[\text { BAIK }]=\left\{\begin{aligned}
0, & y \geq 9 ; \\
\frac{y-2}{9-2}, & 2 \leq x \leq 9 ; \\
1, & x \leq 2 ;
\end{aligned}\right.
\end{gathered}
$$

Mencari nilai keanggotaan untuk Variabel Kualitas:

$\mu$ Kurang Baik $[8]=(9-8) / 7=0,14$

$\mu$ Baik [8] $=(8-2) / 7=0,85$

[R1] IF Permintaan SEDIKIT AND Kualitas KURANG BAIK THEN Harga MURAH

$$
\begin{aligned}
\text { Pred } 1 & =\min (0,4 ; 0,14) \\
& =0,14 \\
\mathrm{Z1}= & 503.486
\end{aligned}
$$

[R2] IF Permintaan SEDIKIT AND Kualitas BAIK THEN Harga MURAH

Pred $2=\min (0,4 ; 0,85)$

$$
=0,4
$$

$\mathrm{Z} 2=508.679$

[R3] IF Permintaan BANYAK AND Kualitas BAIK THEN Harga MAHAL

Pred $3=\min (0,6 ; 0,85)$

$$
=0,6
$$

$\mathrm{Z} 3=518.750$

[R4] IF Permintaan SEDIKIT AND Kualitas KURANG BAIK THEN Harga MAHAL

$$
\begin{gathered}
\text { Pred } 4=\min (0,4 ; 0,14) \\
=0,14 \\
\mathrm{Z} 4=520.750
\end{gathered}
$$

[R5] IF Permintaan BANYAK AND Kualitas KURANG BAIK THEN Harga MAHAL

$$
\begin{aligned}
\text { Pred5 } & =\min (0,6 ; 0,14) \\
& =0,14 \\
\mathrm{Z} 5 & =520.600
\end{aligned}
$$

[R6] IF Permintaan SEDIKIT AND Kualitas BAIK THEN Harga MAHAL

$$
\begin{aligned}
\text { Pred6 } & =\min (0,4 ; 0,85) \\
& =0,4
\end{aligned}
$$

$\mathrm{Z} 6=521.543$

\section{c. Proses Defuzzyfikasi}




$$
\begin{aligned}
& \left(\alpha-\operatorname{Pred} 1 * z_{1}\right)+\left(\alpha-\operatorname{Pred} 2 * z_{2}\right)+\left(\alpha-\operatorname{Pred} 3 * z_{3}\right) \\
& Z=\frac{+\left(\alpha-\operatorname{Pred} 4 * z_{4}\right)+\left(\alpha-\operatorname{Pred} 5 * z_{5}\right)+\left(\alpha-\operatorname{Pred} 6 * z_{6}\right)}{\alpha-\operatorname{Pred} 1+\alpha-\operatorname{Pred} 2+\alpha-\operatorname{Pred} 3+} \\
& \alpha-\text { Pred } 4+\alpha-\text { Pred5 }+\alpha-\text { Pred6 } \\
& =\frac{(0,14 * 503.486)+(0,4 * 508.679)+(0,6 * 518.750)+(0,14 * 520.750)+(0,14 * 520.600)+(0,4 * 521.543)}{(0,14+0,4+0,6+0,14+0,14+0,4)}
\end{aligned}
$$$$
=516.272,4395
$$

Jadi, menurut perhitungan di atas hasil memprediksi harga emas 24 karat per gram nya Rp.516.272,4395.

\section{Kesimpulan}

Berdasarkan hasil pengujian dan analisis yang telah dilakukan dapat disimpulkan bahwa metode fuzzy sugeno dapat digunakan untuk menyelesaikan permasalahan yang terjadi pada harga emas 24 karat di kota medan dengan menggunakan variable permintaan, kualitas dan harga. Hasil dari perhitungan yang telah dilakukan maka dapat di prediksi bahwa hasil dari harga emas jika permintaan 20 dan kualitas 8 untuk emas 24 karat per gram nya di kota medan adalah Rp.516.272,4395. Dari hasil tersebut maka dapat mempermudah toko emas di medan dalam memprediksi hasil harga emas per gram nya

\section{Daftar Pustaka}

[1] Meimaharani, R., \& Listyorini, T. (2014). Analisis Sistem Inference Fuzzy Sugeno Dalam Menentukan Harga Penjualan Tanah Untuk Pembangunan Minimarket. Jurnal SIMETRIS, Vol 5 No 1 April 2014, 89-96.

[2] Rahakbauw, D. L. (2015). Penerapan Logika Fuzzy Metode Sugeno Untuk Menentukan Jumlah Produksi RotI. Barekeng: Jurnal Ilmu Matematika dan Terapan | Desember 2015 | Volume 9 Nomor 2, 121-134.

[3] Siallagan, S. A., \& Sahara, W. (2020). Penerapan Fuzzy Sugeno dalam Usaha Roti Ketawa. KESATRIA: Jurnal Penerapan Sistem Informasi (Komputer \& Manajemen) Vol. 1, No. 2, April (2020), 73-76.

[4] Sitio, S. L. (2018). Penerapan Fuzzy Inference System Sugeno Untuk Menentukan Jumlah Pembelian Obat (Studi Kasus: Garuda Sentra Medika. Jurnal Informatika Universitas Pamulang 104 Vol. 3, No. 2, Juni 2018, 105-109.

[5] Sugumonrong, D. P., Handinata, A., \& Tehja, A. (2019). Prediksi Harga Emas Menggunakan Metode Fuzzy Time Series Model Algoritma Chen. Informatics Engineering Research And Technology Volume 1 NO.1, 48-54. 